УДК 656.09

\title{
ЗМІСТОВНО-ДЕФІНІТИВНЕ НАВАНТАЖЕННЯ ПОНЯТТЯ «ІНФРАСТРУКТУРА» СТОСОВНО ТРАНСПОРТНОГО РИНКУ
}

\section{CONTENT-DEFINITIVE LOAD OF THE CONCEPT OF «INFRASTRUCTURE» IN RELATION TO THE TRANSPORT MARKET}

\author{
Труніна Ірина Михайлівна \\ доктор економічних наук, профресор, \\ Кременчуцький національний університет імені Михайла Остроградського \\ ORCID: https://orcid.org/0000-0002-7416-1830 \\ Латишев Костянтин Олександрович \\ кандидат економічних наук, доцент, \\ Кременчуцький національний університет імені Михайла Остроградського \\ ORCID: https://orcid.org/0000-0003-2645-1902 \\ Андрієнко Марія Сергіївна \\ магістр, \\ Кременчуцький національний університет імені Михайла Остроградського \\ ORCID: https://orcid.org/0000-0002-5632-5758
}

\author{
Trunina Iryna, Latyshev Kostiantyn, Andrienko Mariya \\ Kremenchuk Mykhailo Ostrogradskyi National University
}

\begin{abstract}
Стаття присвячена широкому комплексу проблем, пов'язаних з теоретико-методологічними аспектами вивчення категорії «інфраструктура». Виявлено основні підходи до виникнення інфраструктури як поняття та категорії: хронологічний, етимологічний, економічний. Визначено особливості фрормування інфрраструктури транспортного ринку, визначено ії̈ сутність та вплив на розвиток країни. Обгрунтовано застосування транспортної доступності як визначального критерію результативності використання інорраструктури транспортного ринку. Поглиблено змістовно-десрінітивне навантаження поняття «інфрраструктура транспортного ринку» 3 метою відображення зв'язку економічного простору в параметрах обсягу перевезених вантажів і кількості пасажирів, часу та якості в процесі задоволення потреб суспільства в переміщенні вантажів.
\end{abstract}

Ключові слова: транспортний ринок, інфраструктура, дефініція, національна економіка, наукові підходи.

Статья посвящена широкому комплексу проблем, связанных с теоретико-методологическими аспектами изучения категории «инфрраструктура». Выявлены основные подходы к возникновению инсраструктуры как понятия и категории: хронологический, этимологический, экономический. Определены особенности формирования инфрраструктуры транспортного рынка, ее сущность и влияние на развитие страны. Обосновано применение транспортной доступности как определяющего критерия результативности использования инсраструктуры транспортного рынка. Расширена содержательно-дефинитивная нагрузка понятия «инфрраструктура транспортного рынка» с целью отражения связности экономического пространства в параметрах объема перевезенных грузов и количества пассажиров, времени и качества в процессе удовлетворения потребностей общества в перемещении грузов.

Ключевые слова: транспортный рынок, инфраструктура, десиниция, национальная экономика, научные подходы.

The state of the transport industry is an important determinant of progressive changes in the economy and society of each country. Developed transport market infrastructure is one of the most important factors in the dynamic growth of the domestic economy, the basic prerequisite for the country's integration into the world economic space, providing an important impetus for the spatial division of labor and development of new territories. The article is devoted to a wide range of problems associated with theoretical and methodological aspects of studying the category of «infrastructure». The main approaches to the emergence of infrastructure, as concepts and categories: 
chronological, etymological, economic. The peculiarities of the formation of the transport market infrastructure are determined, its essence and influence on the country's development are determined. The use a transport accessibility as a determining criterion for the effectiveness of the use of transport market infrastructure is substantiated. The content-definitive load of the concept of «transport market infrastructure» is deepened in order to reflect the relationship of economic space in the parameters of the volume of transported goods and the number of passengers, time and quality in the process of meeting the needs of society in moving goods. Proposed the following definition of «transport market infrastructure» - a set of economic relations in the national economy that provide transport and economic links between businesses for the constant movement of passenger and freight flows, which contributes to the reproduction of the transport model optimally forming and managing transport infrastructure the process of meeting the needs of society. It is proved that the economic content of the transport market infrastructure is revealed through a number of its functions (providing, regulating, stimulating, social, productive, foreign economic, national security), the implementation of these functions of the transport market infrastructure directly affects the efficiency of transport, business activity domestic product, national security and social welfare of the population.

Keywords: transport market, infrastructure, definition, national economy, scientific approaches.

Постановка проблеми. Стан транспортної галузі є вагомою детермінантою прогресивних змін в економіці і соціумі кожної країни. У той же час, це базовий індикатор рівня розвитку держави $з$ погляду забезпечення якості життя населення, сприятливого середовища економічного зростання і підприємницької діяльності. Дослідницький актуалітет підтверджує різнобічне значення транспортної інорраструктури у фрокусі трансорормаційних змін національної економіки. У період економічного відновлення України помітно посилилась увага до інсрраструктури транспортного ринку, оскільки розвиток останньої $€$ однією 3 передумов стійкого розвитку національної економіки загалом. Стратегічна значущість розвитку транспортної інфрраструктури в країні для економічної безпеки держави в умовах загострення зовнішніх та внутрішніх протиріч та обмеження ресурсів, вимагає від держави максимального використання міжнародного досвіду щодо ресрормування цієї ссрери та застосування нестандартних стратегічних рішень. Багатоаспектність поняття «інфрраструктура транспортного ринку» підтверджується плюралізмом його десініцій 3 позиції дослідників та неоднозначністю в процесі визначення змісту. У цьому контексті особливої актуальності набуває дослідження змістовно-десрінітивного навантаження поняття «інфрраструктура» стосовно транспортного ринку.

Аналіз останніх досліджень і публікацій. Слід зазначити, що проблеми розвитку інфрраструктури знаходять більш широке висвітлення в наукових працях вітчизняних і зарубіжних дослідників: О. Богуславського, І. Бойчика, К. Генріх-Франке, Х. Зінгера, Н. Іванової, Р. Йохімсена, П. РозенштейнРодана. Проблеми розвитку інфраструктури транспортного ринку розглядалися такими відомими науковцями як Н. Бондар, Ю Єнін, Н. Лисяк, О. Новікова, С. Пирожков, Н. Подобед, І. Садловська, В. Шемаєв.
Виділення невирішених раніше частин загальної проблеми. Незважаючи на широкий спектр досліджень 3 даної проблематики, в науковому середовищі недостатньо уваги приділяється вивченню десрініції «індрраструктура транспортного ринку».

Формулювання цілей статті (постановка завдання). Проведені дослідження дають підстави стверджувати, що сьогодні не сорормовано категорійного базису, концепції та методологічних засад реалізації важливішої функції державного регулювання - управління розвитком інфрраструктури транспортного ринку. У зв'язку з цим метою даної статті $€$ поглиблення змістовно-десрінітивного навантаження поняття «інфрраструктура транспортного ринку» та аналіз наукових підходів щодо визначення його сутності.

Виклад основного матеріалу дослідження. Розвинена індрраструктура транспортного ринку є одним з найважливіших чинників динамічного зростання вітчизняної економіки, базовою передумовою інтеграції країни у світовий економічний простір, надаючи важливий імпульс для просторового розподілу праці та освоєння нових територій. У випадку ж недостатньої координації інфрраструктури транспортного ринку має місце нераціональне використання ресурсів, що призводить до зниження рівня конкурентоспроможності національної економіки.

Поняття «інорраструктура» у різноманітних літературних джерелах розглядається у розрізі галузевої приналежності, а не як цілісна система, від рівня розвитку котрої залежить есрективність фрункціонування усіх елементів ринкової економіки, виходячи із синергії їх взаємодії. Відсутність єдиної позиції щодо трактування цього поняття призводить до невдалих спроб управління розвитком інорраструктури, значущість якої особливо посилюється із превалюванням сорери послуг над виробництвом. 
Якщо виходити 3 авторських трактувань генезису інфрраструктури, як економічної категорії, то можна позначити таку особливість: в економічній теорії дотепер немає чіткого розуміння, хто з дослідників першим ввів у науковий обіг економічну категорію «інсрраструктура». Так, американська економічна школа вважає, що першим дослідником, який використовував даний науковий термін у 1955 р. був американський вчений П. Розенштейн-Родан, який у своїх працях зазначав,що «...перед будівництвом фрабрик необхідно спонсорувати створення великої маси інфрраструктурного капіталу, тому що виключно ринкові механізми не створять інсрраструктуру вчасно» [1, с. 45]. У його дослідженнях інфрраструктура трактувалася як головна умова економічного зростання, відповідно елементи інфраструктури виділялися на основі галузевої структури економіки.

Інші науковці вважають «батьком» терміна «інфраструктура» X. Зінгера, який у 40-х роках XX ст. запропонував термін «social overhead capital» близький до сучасного трактування категорії «інфрраструктура». Вчений висунув концепцію «збалансованого зростання за допомогою незбалансованих інвестицій», згідно з якою якісне зростання основних економічних показників досягається за рахунок формування власної виробничої та соціальної інфрраструктури [2, с. 21].

Але ж найбільш широке трактування категорії «інфрраструктура» за тих часів належить Р. Йохімсену. Дослідник дає визначення інфраструктури як «суми матеріальних, інституціональних та особистих коштів, а також інорормації, доступної економічним агентам, яка сприяє вирівнюванню рівня віддачі при порівнянних інвестиціях у разі відповідного розподілу ресурсів, тобто при повній інтеграції та максимізації рівня економічної активності» [3, с. 16].

Таким чином, західна економічна школа здебільшого розглядала інсрраструктуру як складову частину загальних умов антрепренерства, що дозволяє знизити транзакційні витрати при веденні бізнесу та сприяє досягненню економічного зростання.

Маркетингова концепція вивчення ринкової інсрраструктури спочатку орієнтувалася на мікрорівень. Починаючи з 70-х рр. XX ст. при дослідженні інфрраструктури став застосовуватися макромаркетинговий підхід, який передбачав вивчення елементів інфраструктури на основі теорії суспільного відтворення.

Незважаючи на значний науковий інтерес до теорії інфрраструктури, ії̈ взаємозв'язок із сучасними економічними теоріями та концеп- ціями, нині немає загальноприйнятного підходу до розуміння сутності цієї категорії. Розглянемо більш детально вже ссрормовані в науковому просторі концептуальні положення пізнання змісту цієї десрініції.

Так, Н. Іванова, провівши аналіз сутності економічної категорії «інфрраструктура», виділяє такі теоретико-методологічні підходи до ії визначення: теоретико-економічний, інституціональний, структурно-фрункціональний, комплексний [4]. Певні інвайроментальні зміни трактування категорії «інфрраструктура» пов'язані з екологізацією соціуму та активним застосуванням біоссрерного підходу спостерігаються у працях вченого Б. Фрішмана [5]. Еволюція ринкової інфрраструктури ототожнювалася авторами з успішним розвитком національної системи підприємництва як визначального фрактора економічного зростання [6]. Інфрраструктура трансфрормувалася в головний фрактор розвитку національної економіки та зміцнення конкурентоспроможності [7].

У науковій літературі $є$ істотні розбіжності в трактуванні поняття «інфрраструктура», її складу, класифрікації та елементів. Загальні недоліки розуміння «інфрраструктура» обумовлені різноманітністю підходів до виникнення даної категорії, запропонованих різними авторами, які належать до різних наукових шкіл. На основі вивчення вітчизняних та зарубіжних джерел було виділено такі базові недоліки:

1. Частина авторів трактує термін «інфрраструктура» як систему організацій адекватних ринковому механізму [8, с. $179 ; 9$, с. 26]. При цьому застосовується виключно прикладне сприйняття інфрраструктури як елемента, що виконує в економіці заздалегіть певні незмінні срункції, що залежать від галузевої структури економіки, що не відповідає сучасним явищам конвергентності та багатофрункціональності;

2. Зміст десрініцій «інфрраструктура» різних авторів не відображає перелік соціально-економічних відносин, що виникають у наслідок комерційного використання елементів інфрраструктури [10, с. $164 ; 11$, с. $74 ; 12$, с. 39$].$

3. Описані елементи інфрраструктури фрормують закритий перелік елементів, не полишаючи можливості для додавання нових видів інсрраструктур [13, с. 4]. Так, наприклад, на базі теорії «Нова енергетична цивілізація» досить активно відбувається генерація нового виду транспортно-енергетичної інорраструктури.

4. Більшість дослідників повністю ігнорує найважливіший вид транспортно-логістичної інфрраструктури, який визначено нами як придорожно-сервісний [14, с. 236; 15, с. 330]. 
Для зниження невизначеності при дослідженні необхідно розглянути сутність категорії «інфрраструктура транспортного ринку» через призму базових економічних теорій. Підгрунтям для такого аналізу можуть слугувати теорії просторового розміщення, економічного зростання та науково-технічного прогресу.

У даний час існує ряд підходів до визначення сутності поняття «інорраструктура транспортного ринку», позиція авторів яких пов'язана з профрілем їх наукових інтересів. Так, в економічній теорії міжнародна транспортна система являє собою найважливіший елемент глобальної інфрраструктури. У національній економіці до інфрраструктури транспортного ринку країни відносять рухомий склад і шляхи сполучення територій. У регіональній економіці транспорт відносять до доповнюючих інфрраструктурних галузей регіону.

На думку І. Садловської під інфрраструктурою транспортного ринку слід розуміти комплекс сорер діяльності, що обслуговують ринок, необхідних для переходу економіки до розвинених ринкових відносин [16, с. 51]. Дослідниця запропонувала комплексний підхід, відповідно до якого інфрраструктура транспортного ринку відображає сукупність економічних відносин в національній економіці, що забезпечують фрормування й використання транспортно-економічних зв'язків між суб'єктами господарювання для безперебійного руху пасажирських та вантажних потоків, а також надання комплексу супровідних послуг, що в сукупності сприяє відтворенню елементів національної економіки [16, с. 56]. Відмінною рисою даного визначення $€$ діалектика, яка полягає в тому, що інорраструктура транспортного ринку відображає певні економічні відносини, що складаються в активних до транспортування галузях, з одного боку, та у забезпеченні ефективного переміщення товрів і послуг до кінцевого споживача, з іншого.

Н. Бондар розглядає інфрраструктуру транспортного ринку як єдиний технологічний комплекс, що діє на основі двох базових складових: транспортної мережі, що використовується для перевезення вантажів та пасажирів і під якою розуміються наземні, водні та повітряні шляхи сполучення та організаційної структури, призначеної для есрективного управління транспортними засобами та постійними пристроями транспортної мережі $[17$, с. 56]. Розвиваючи думку та поглиблюючи змістовне навантаження даної десрініції автор доповнює власне визначення у більш широкому розумінні та пропонує розглядати транспортну інфрраструктуру як цілеорієнтовану підсистему транспорту, складовими якої є: 1) транспортні комунікації; 2) об'єкти з обслугову- вання вантажних та пасажирських перевезень; 3) об'єкти технічного обслуговування та ремонту; 4) державні та приватні інститути і суб'єкти господарювання, що фрункціонують у сорері транспортної інсрраструктури; 5) система управління розвитком транспортної інфрраструктури [17, с. 59].

Вагомий внесок у вдосконалення десрініції транспортної інфрраструктури зробив С. Пирожков, який підкреслив основне призначення інорраструктури транспортного ринку-забезпечення ефективних зв'язків між суб'єктами виробничих відносин. Дослідник зазначив, що інсрраструктура транспортного ринку - це система організацій, що забезпечують взаємозв'язки між структурними елементами товарних ринків і сприяють вільному руху товарів, безперервному відтворювальному процесу й безперебійному фрункціонуванню сорер кінцевого споживання [18, с. 24].

Низка вчених розглядають інсрраструктуру транспортного ринку з позиції інституціонального підходу, визначаючи останню як комплекс інститутів, що забезпечують нормальне, безперервне фрункціонування транспортного об'єднання виробників [19, с. 41].

3 точку зору джерела можливостей зміцнення економічної безпеки та інструменту нейтралізації загроз розглядає інсрраструктуру транспортного ринку В. Шемаєв. Автор ствержує, що остання $є$ складовою частиною єдиної транспортної системи, що покликана забезпечити умови її фрункціонування,завдяки чому створює можливості зміцнення економічної безпеки держави та гарантує спроможність держави до превентивного захисту від ризиків та загроз у транспортній сорері на національному та міжнародному рівні [20, с. 57].

Отже, пропонуємо наступне визначення поняття «інфрраструктура транспортного ринку» - сукупність економічних відносин в національній економіці, що забезпечують транспортно-економічний зв'язок між суб'єктами господарювання для постійного руху пасажиро- і вантажопотоків, що сприяє відтворенню транспортної моделі оптимально фрормуючи й управляючи транспортною інсрраструктурою в процесі задоволення потреб суспільства.

Тож маємо резюмувати, що процес фрормування транспортної інсрраструктури є вельми складним, безперервним і передбачає активну участь усіх без винятку суб'єктів відносин у системі національної економіки. Особливо це виявляється за особистої участі державних органів управління на основі використання економічного й правового регулювання. Перехід від централізовано регульованої економіки до ринкового господарства спричинив зміну 
відтворювальної структури економіки і, відповідно, якісну зміну транспортної інфрраструктури за властивостями, видами, фрормою.

Висновки. Перебуваючи в тісній економічній взаємодії з усіма елементами транспортної системи, інфрраструктура транспортного ринку $\epsilon$ ключовою умовою розвитку всіх суб'єктів господарювання та економіки в цілому. Інфраструктура транспортного ринку має бути адекватна і відбивати рівень розвитку виробництва на кожному етапі еволюції суспільства.

Економічний зміст інфрраструктури транспортного ринку країни розкривається через низку її функцій (забезпечуючу, регулюючу, стимулюючу, соціальну, продуктивну, зовнішньоекономічну, національної безпеки), реалізація цих фрункції інфрраструктури транспортного ринку безпосередньо впливає на ефективність функціонування транспортної галузі, ділова активність та обсяг валового внутрішнього продукту, національна безпека та суспільний добробут населення країни. Це зумовлює взаємозв'язок інфрраструктури транспортного ринку з реалізацією національних економічних інтересів та віднесення цієї ссрери до складу стратегічних галузей, які перебувають під контролем держави.

\section{СПИСОК ВИКОРИСТАНИХ ДЖЕРЕЛ:}

1. Rosenstein-Rodan, P. N. Notes on the Theory of the «Big-Push». Economic Development for Latin America : proc. of a conf. held by the Intern. Econ. Assoc. edited by H. S. Ellis, H. C. Wallich. London : Macmillan, 1961. 60 p.

2. Singer, H. W. International Development: Growth and Change. New York : McGraw-Hill Book Co, 1964. 106 p.

3. Jochimsen, R. Theorie der Infrastructur: Grundlagen der marktwirtschaftlichen Entwicklung. Tubingen : J.C.B. Mohr, 1966. 84 p.

4. Іванова Н. В. Генезис економічної категорії «інсрраструктура» та ії роль у суспільному поділі праці. Ефективна економіка. 2010. № 11. URL: http://www.economy.nayka.com.ua/index.php?operation=1\&iid=392 (дата звернення: 12.05.2021).

5. Frischmann, B. M. Infrastructure: the social value of shared resources. New York : Oxford University Press, 2013. $436 \mathrm{p}$.

6. Ambrosius, G., Henrich-Franke, C. Integration of Infrastructures in Europe in Historical Comparison. Cham : Springer International Publishing, 2016. VII, $210 \mathrm{p}$.

7. Труніна І. М., Латишев К. О. Проблеми забезпечення конкурентоспроможності підприємств транспортної інфрраструктури. Вісник КрНУ імені Михайла Остроградського. 2020. Вип. 5-6 (124-125). С. 24-30.

8. Ясковець Ю. В. Теоретичні аспекти дослідження інсрастурктури національних господарств в умовах глобалізації. Актуальні проблеми міжнародних відносин. 2013. Вип. 114(2). С. 173-180.

9. Енин Ю. И., Подобед Н. А. Инновационный менеджмент. Минск : БНТУ, 2015. 98 с.

10. Садчикова І. Концептуальні положення обгрунтування сутності категорії «інсрраструктура». Проблеми $i$ перспективи економіки та управління. 2020. № 4(24). С. 155-169.

11.Богуславський О. В. Основні підходи до вивчення елементів ринкової інсрраструктури у сучасній економіці та особливості їх застосування. Теоретичні та прикладні питання економіки. 2016. Вип. 1. С. 69-76.

12. Бойчик I. М. Ринкова інфрраструктура: сутність та характеристика. Сталий розвиток економіки. 2013. № 3. C. 34-41.

13.Трубицына Т. И. Инфраструктура как категория экономической теории. Изв. Саратов. ун-та. Сер. Экономика. Управление. Право. 2012. В. 2, т. 12. С. 3-7.

14. Подобед Н. А., Енин Ю. И. Транспортно-логистическая инсрраструктура Евразийского союза: принципы и факторы эволюционного развития. Вес. Нац. акад. навук Беларусі. Сер. гуманітарных навук / гал. рэд. А. А. Каваленя. 2019. Т. 64. № 2. С. 235-241.

15. Лисяк Н. М. Технічна інфраструктура та житлове будівництво м. Львова на зламі XX-XXI ст. Вісник Національного університету «Львівська політехніка». 2013. № 767. С. 326-336.

16. Садловська І. П. Стратегічне управління національною транспортною інфрраструктурою України : монограсрія. Київ : П.П. «Сердюк В.Л.», 2011. 356 с.

17. Бондар Н. М. Розвиток транспортної інфрраструктури України на засадах державо-приватного партнерства : монографрія. Київ, 2014. 336 с.

18. Пирожков С. І. Методичні рекомендації щодо оцінки рівня економічної безпеки України. Київ : НІПНБ, 2003. $42 \mathrm{c}$.

19. Новікова О. Ф., Покотиленко Р. В. Економічна безпека: концептуальне визначення та механізми забезпечення : монограсрія. НАН України, ін.-т. економіки промисловості. Донецьк, 2006. 408 с.

20. Шемаєв В. В. Управління розвитком транспортної інфрраструктури в системі економічної безпеки держави : дис. ... д-ра екон. наук : 21.04.01 / Нац. ін-т стратег. дослід. Київ, 2018. 494 с. 


\section{REFERENCES:}

1. Rosenstein-Rodan, P. N. (1961) Notes on the Theory of the «Big-Push». Economic Development for Latin America: proc. of a conf. held by the Intern. Econ. Assoc. edited by H. S. Ellis, H. C. Wallich. London: Macmillan. $60 \mathrm{p}$.

2. Singer, H. W. (1964) International Development: Growth and Change. New York: McGraw-Hill Book Co., 106 p.

3. Jochimsen, R. (1966) Theorie der Infrastructur: Grundlagen der marktwirtschaftlichen Entwicklung. Tubingen: J.C.B. Mohr, $84 \mathrm{p}$.

4. Ivanova N. (2010) Henezys ekonomichnoi katehorii «infrastruktura» ta yii rol u suspilnomu podili pratsi [The genesis of the economic category «infrastructure» and its role in the social division of labor]. Efektyvna ekonomika - Efficient economy, no. 11. Available at: http://www.economy.nayka.com.ua/index. php?operation=1\&iid=392 (accessed 12 May 2021).

5. Frischmann, B. M. (2013) Infrastructure: the social value of shared resources. New York: Oxford University Press, $436 \mathrm{p}$.

6. Ambrosius, G., Henrich-Franke, C. (2016) Integration of Infrastructures in Europe in Historical Comparison. Cham: Springer International Publishing, VII, $210 \mathrm{p}$.

7. Trunina I. M., Latyshev K. O. (2020) Problemy zabezpechennia konkurentospromozhnosti pidpryiemstv transportnoi infrastruktury [Problems of ensuring the competitiveness of transport infrastructure enterprices]. Visnyk KrNU imeni Mykhaila Ostrohradskoho -Bulletin of Mikhailo Ostrohradskyi KrNU, 5-6 (124-125), pp. 24-30.

8. Yaskovets Yu. V. (2013) Teoretychni aspekty doslidzhennia infrasturktury natsionalnykh hospodarstv v umovakh hlobalizatsii [Theoretical aspects of the study of the infrastructure of national economies in the context of globalization]. Aktualni problemy mizhnarodnykh vidnosyn - Current issues of international relations, no. 114(2). pp. 173-180.

9. Yenin Yu. I., Podobed N. A. (2015) Ynnovatsyonnii menedzhment [Innovation management]. Minsk: BNTU, 98 p.

10. Sadchykova I. (2020) Kontseptualni polozhennia obhruntuvannia sutnosti katehorii «infrastruktura» [Conceptual provisions of substantiation of the essence of the category«infrastructure»]. Problemy i perspektyvy ekonomiky ta upravlinnia - Problem and prospects of economics and management, no. 4(24), pp. 155-169.

11.Bohuslavskyi O. V. (2016) Osnovni pidkhody do vyvchennia elementiv rynkovoi infrastruktury u suchasnii ekonomitsi ta osoblyvosti yikh zastosuvannia [The main approaches to the study of elements of market infrastructure in the modern economy and features of their application]. Teoretychni ta prykladni pytannia ekonomiky - Theoretical and applied issues of economics, no. 1, pp. 69-76.

12. Boichyk I. M. (2013) Rynkova infrastruktura: sutnist ta kharakterystyka [Market infrastructure essence and characteristics]. Stalyi rozvytok ekonomiky - Sustainable economic development, no. 3, pp. 34-41.

13. Trubytsina T. Y. (2012) Infrastruktura kak katehoryia ekonomycheskoi teoryiy [Infrastructure as a category of economic theory]. Izv. Saratov. un-ta. Ser. Ekonomyka. Upravlenye. Pravo. - Izv. Saratov. un-ta. Ser. Economics. Management. Right, no. 2, p. 12, pp. 3-7.

14. Podobed N. A., Yenyn Yu. I. (2019) Transportno-lohystycheskaia infrastruktura Evrazyiskoho soiuza: pryntsypy y faktory evoliutsyonnoho razvytyia [Transport and logistics infrastructure of the Eurasian Union: principles and factors of evolutionary development]. Ves. Nats. akad. navuk Belarusi. Ser. humanitarnikh navuk / hal. red. A. A. Kavalenia - Weigth Nat. acad. Of Sciences of Belarus. Ser. humanities / A. A. Kavalenya, no. 64, p. 2, pp. 235-241.

15. Lysiak N. M. (2013) Tekhnichna infrastruktura ta zhytlove budivnytstvo m. Lvova na zlami XX-XXI st. [Technical infrastructure and housing construction of Lviv at the turn of the XX-XXI centuries]. Visnyk Natsionalnoho universytetu «Lvivska politekhnika» - Bulletin of the National University «Lviv Polytechnic», no. 767, pp. 326-336.

16. Sadlovska I. P. (2011) Stratehichne upravlinnia natsionalnoiu transportnoiu infrastrukturoiu Ukrainy [Strategic management of national transport infrastructure of Ukraine]: monohrafiya [a monograph]. Kyiv: PP «Serdyuk V. L.», $356 \mathrm{p}$.

17. Bondar N. M. (2014) Rozvytok transportnoi infrastruktury Ukrainy na zasadakh derzhavo-pryvatnoho partnerstva [Development of transport infrastructure of Ukraine on the basis of public-private partnership]: monohrafiya [a monograph]. Kyiv, $336 \mathrm{p}$.

18. Pyrozhkov S. I. (2003) Metodychni rekomendatsii shchodo otsinky rivnia ekonomichnoi bezpeky Ukrainy [Methodical recommendations for assessing the level of economic security of Ukraine]. Kyiv: NIPNB, $42 \mathrm{p}$.

19. Novikova O. F., Pokotylenko R. V. (2006) Ekonomichna bezpeka: kontseptualne vyznachennia ta mekhanizmy zabezpechennia [Economic security: conceptual definition and support mechanisms]. monohrafiya [a monograph]. NAS of Ukraine. Industrial economics institute. Donetsk, $408 \mathrm{p}$.

20. Shemaiev V. V. (2018) Upravlinnia rozvytkom transportnoi infrastruktury v systemi ekonomichnoi bezpeky derzhavy [Management of transport infrastructure development in the system of economic security of the state]. Doctor's thesis. Kyiv. (in Ukrainian) 